\title{
TENSION GASHES EXPLORE THE STRUCTURAL DEFORMATION OF MINERALIZED SHEAR ZONE AT WADI BELIH, NORTHERN EASTERN DESERT, EGYPT.
}

\author{
Waheeb, A. G. "'t \\ * Subsurface Geology Department, Nuclear Materials Authority, P.O. Box 530, \\ El Maadi, Cairo, Egypt. \\ †Email:-Anton_oon@yahoo.com.
}

\begin{abstract}
The sigmoidal tension gashes are very important markers in the determination of deformation, which affected $\mathrm{W}$. Belih area. They are markers for the determination of shear zone type (brittle shear zone). In addition, the tension gashes are used as strain markers for assessing strain localization in shear zones. The shear plane in association with its tension gashes determines the stress axes responsible for the formation of this tensile shear zone. W. Belih uranium mineralization in the area under consideration (G$\mathrm{V}$ occurrence) is located along a tectonic shear contact zone between the Hammamat sedimentary rocks and younger Gattarian granites. The detailed structural analysis for this shear zone by using tension gashes indicated that the shear zone in association with its tension gashes gives an extension regime from NW-SE direction; this extension force is the main extensional force affecting the G-V mineralized shear zone and is responsible for distribution and localization of secondary uranium minerals along the contact shear zone. In addition, the strain analysis from a given tension gashes array indicates that the rate of dilatation relative to boundary-parallel shear is greatest as the finite strain is low $(\gamma=0.27)$, so that space is created rapidly for the precipitation of minerals.
\end{abstract}

Keywords: shear zone, sigmoidal tension gashes, structural analysis and G. Gattar area.

\section{INTRODUCTION}

The investigated area is located at the intersection of Latitude $27^{\circ} 7^{\prime} 30^{\prime \prime} \mathrm{N}$ and Longitude $33^{\circ} 17^{\prime} 5^{\prime \prime} \mathrm{E}$ (Fig. 1). The nearest town is Hurghada; which lies on the Red Sea coast. The main rock types exposed in the studied area are the Hammamat sedimentary rocks in association with younger Gattarian granites (Fig. 2).

W. Belih area has been dealt with by many authors as it is one of the most important uranium occurrences in the northern eastern desert. Among those authors (El Shazly 1970; Dardir and Abu Zied 1972; Willis et al. 1988; Salman et al.1986; El Sirafy and Rabi 1989; Shalaby 1990; El Rakaiby and Shalaby 1992; Roz 1994; Abdel-Hamid 2006; Mahdy et al. 2013).

W. Belih uranium occurrence $(\mathrm{G}-\mathrm{V}$ uranium occurrence) can be considered as a possible potential deposit for uranium (U), rare earth elements (REE )+ Y(yttrium), and other rare metals, as well as the mineralization, are caused by alkaline and oxidizing hot fluids, with the contribution of meteoric water volume heated by convection. The hot fluids flowed up along ENE-WSW and NE-SW faults to cause a rather complicated series of metasomatic reactions. The rare metals were mobilized from the younger 
granite pluton of Gattar and concentrated at the contact. The reaction of the mineralizing solutions with Wall rocks and the pseudomorphic oxidation of pyrite caused the reduction and fixation of uranium (El Kammar et al. 2001). X-ray diffraction technique identifies uranophane and tyuyamunite as secondary uranium minerals for the uranium mineralizations at the studied area (Mahdy et al. 1990; Mahdy 1999).

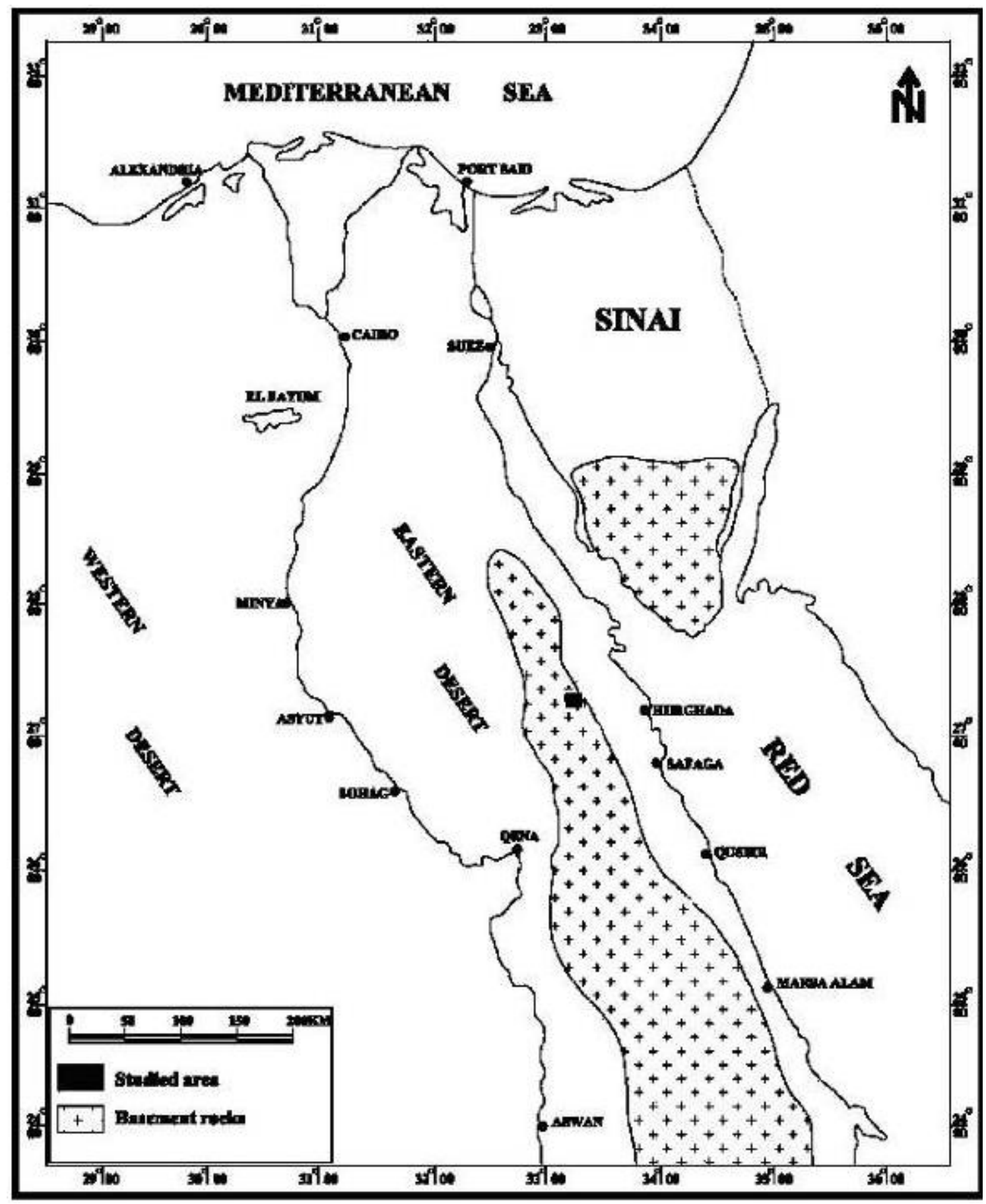

Fig. 1: Location map of W. Belih area, Northern Eastern Desert, Egypt. 


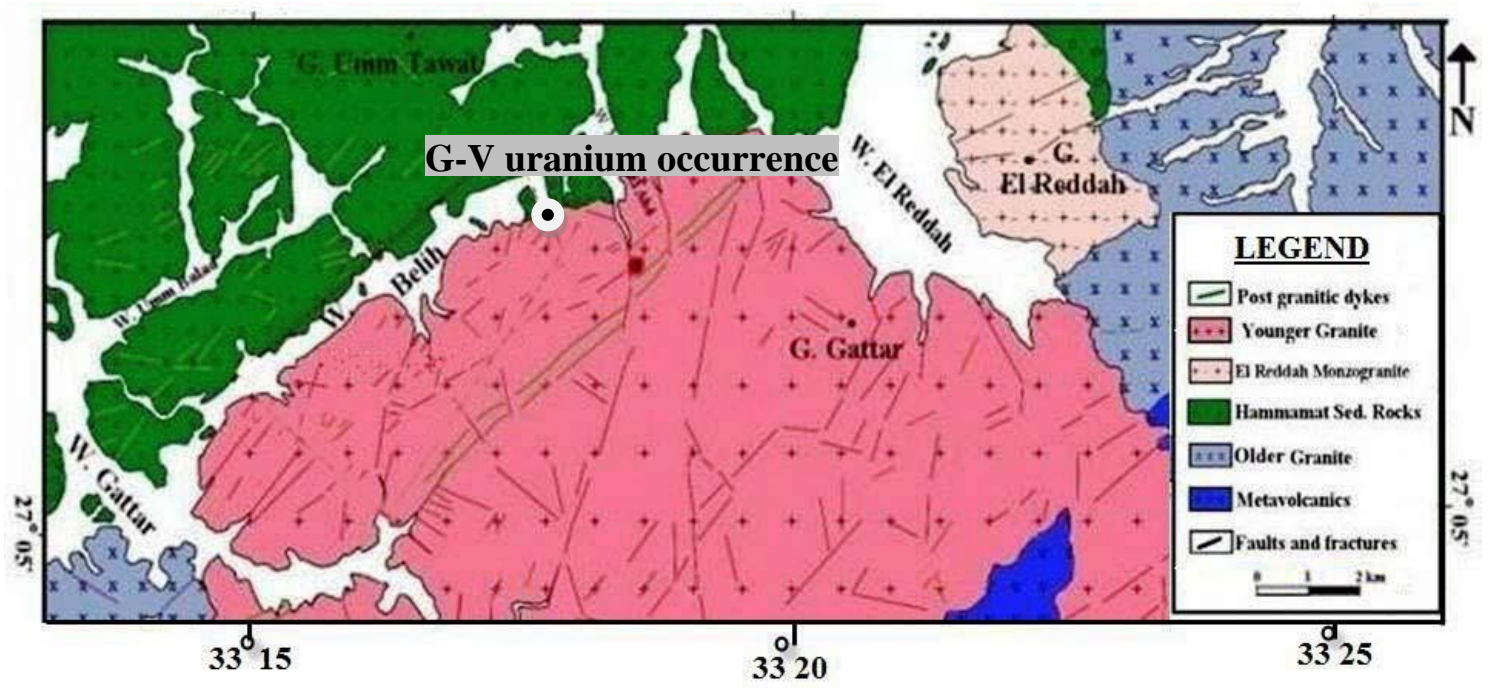

Fig. 2: Geological map of W. Belih (G-V) uranium occurrence, W. Belih area Northern Eastern Desert, Egypt, after El Rakaiby and Shalaby (1992).

The major mineralization-controlling structures along the contact shear zone of W. Belih area record a complex history of deformations where the uranium mineralization are located along the footwall of a shear zone striking ENE-WSW to NE-SW and dips $45^{\circ}-73 \circ$ to SE. This shear zone was reactivated during its tectonic history starting from compression trending NW-SE and NE-SW respectively to younger extensional event trending NW-SE (Waheeb and El Sundoly 2016) and the detailed subsurface structural studies of G-V occurrence in mining works revealed the presence of a major subsurface uranium mineralized trends recorded in the main adit and the drift mostly having ENE WSW and NE-SW directions (Amin 2010).

The Pan African orogenic belt in Egypt is dissected by two right-lateral shear zones trending ENE-WSW to NE-SW, complementary to the left lateral Najd fault systems in the Arabian Shield, shearing also took place during the Pan African orogenic c. 670-550 Ma (El Gaby 1983).

The major shear zones in the Eastern Desert of Egypt have been created by compression from the east, the first order left lateral NW-SE trending Najd shears in the Arabian shield (Schmidet et al, 1979) and its complimentary right lateral NE-SW trending QenaSafaga and ENE-WSW trending Idfu -Marsa Alam shears ( EL Gaby 1983) in the Eastern Desert (Fig. 3). Qena-Safaga NE-SW trending shear zone, at a nearly right angle to the Red Sea, separate remobilized older continental and infolded Dokhan volcanics and molasse Hammamat sedimentary rocks to the north from ophiolites and metavolcanics to the south (El Gaby 1983); this shear zone is semiductile- semibrittle shear zone and it has a long tectonic history since the Precambrian time (Hamimi 1999). This active tectonic zone till the present time (El Kazzaz, 1999) shows a dextral sense of shear and reactivated. Its reactivation during Tertiary is responsible for the creation of Qena bend in the course of Nile River (El Gaby et al. 1988). 


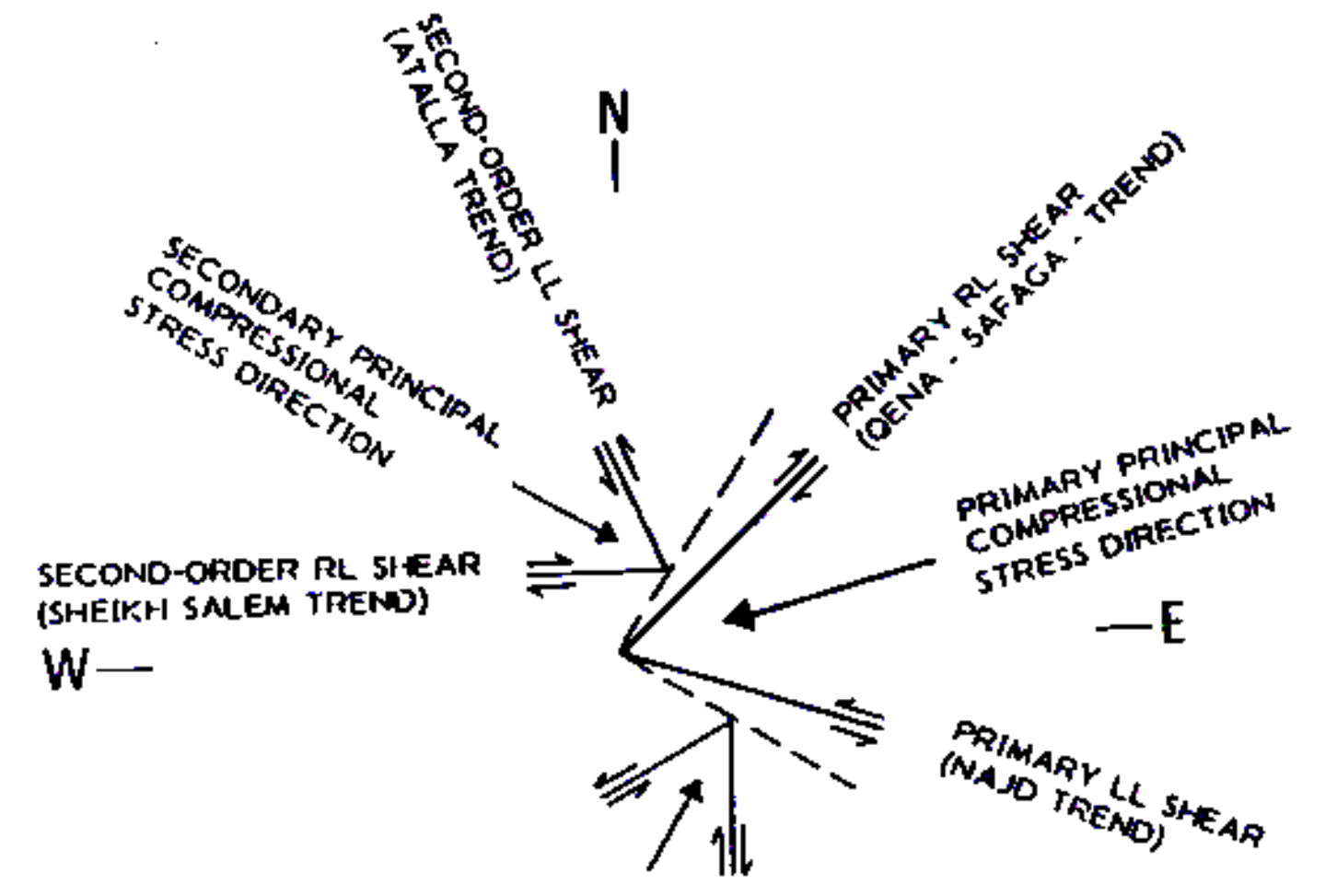

Fig. 3: Major shear trends in the Eastern Desert of Egypt, after El Gaby et al. (1988).

This paper reviews the structural anatomy of the G-V radioactive shear zone at W. Belih area by using sigmoidal tension gashes to better understand the structural deformation, which affected this radioactive shear zone and is responsible for the localization of uranium minerals. This anatomy is easy and fast structural exploration for new areas contains sigmoidal tension gashes. This structural anatomy is compared and improved by the previously different types of structural analysis studies, at the investigated area, to indicate that this method of structural exploration is useful.

\subsection{Structure}

The author in this paper will analyze and describe in detail the shear zone of G-V uranium occurrence (Fig .4) which is responsible for the localization of uranium minerals in the investigated area by using sigmoidal tension gashes to clarify the type of this shear, extensional regimes which affected on the G-V mineralized tensile shear 
zone which responsible for distribution and localization of secondary uranium minerals and detect the amount of finite strain $(\gamma)$ for this shear zone.

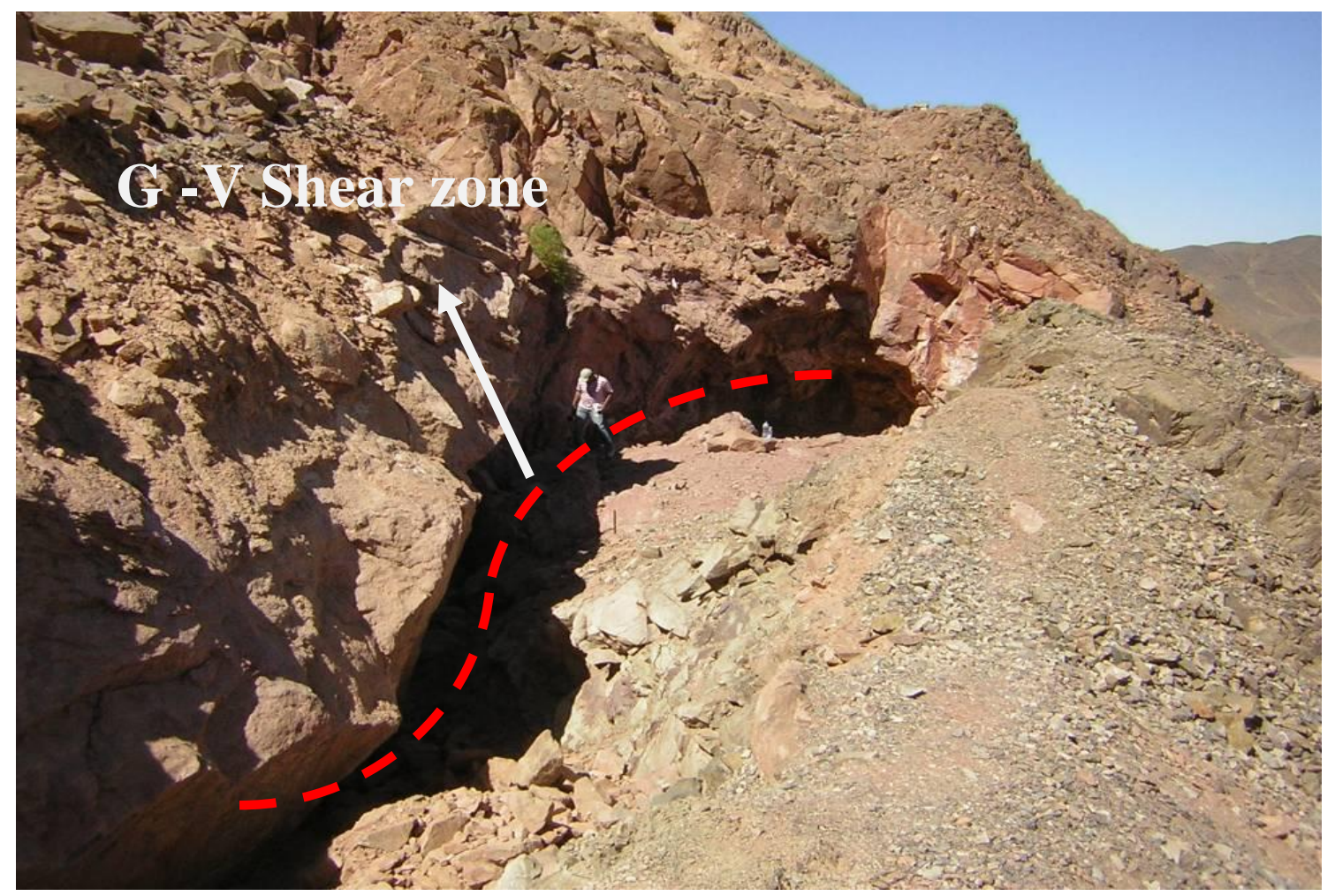

Fig. 4: General view for mineralized shear zones of G-V uranium occurrence, looking W, W. Belih area.

The area under consideration is subjected to four successive tectonic events (Waheeb and El Sundoly 2016). The oldest event (NW-SE extensional event) is during postHammamat sedimentary rocks pre-G. Gattar granite time spam (484 Ma; Hashad 1980). The emplacement of younger granite induced the meso-folds at the Hammamat sedimentary beds at their contacts followed by NW-SE compressional event (second tectonic event) that induced NNW-SSE sinistral and NW-SE dextral strike-slip faults and ENE-WSW reverse fault (the G-V shear zone mineralized contact). The older movement along the ENE-WSW faults trend is assigned to be of Late Carboniferous to Permian in age (El Ramly et al. 1971); the NE-SW compressional event is the third phase that affected the investigated area which induced mesoscopic folds in Hammamat rocks and also induced NE-SW dextral faults followed by the fourth NW-SE extension event which rejuvenate ENE-WSW to NE-SW fault (the G-V shear zone mineralized contact) accompanied by injection of post granitic dykes. The rejuvenated and younger movement along the ENE-WSW faults trend has been dated to be of Late Cretaceous age (El Ramly et al. 1971). This zone is most probably related to Qena - Safaga shear zone and multitudes of ENE-WSW to NE-SW shear faults and zones dissecting the basement and cutting across the Gulf of Suez and the north Red Sea might represent rejuvenation of the old Qena - Safaga shear zone (EL Gaby 1983). 
A variety of minor structures, commonly found in association with shear zones are formed in response to this stress. One of the most common is tension gashes filled with mineralization. They originate parallel to the maximum principle compression.

Commonly, the maximum principle compressive stress acts at $45^{\circ}$ to the shear zone margins (figures 5a, b and 6), and are often arranged en echelon within the shear zone with progressive deformation the veins may rotate but, because the orientations of the principle stresses are fixed with respect to the shear zone margin, the veins will continue to grow at $45^{\circ}$ to the margin. This result in the formation of curved or sigmoidal tension veins (figures $5 \mathrm{c}$ and $\mathrm{d}$ ). The amount of rotation of veins reflects the amount of shear. This will vary along the length of the shear zone, being maximum in the central region, A, and minimum at the shear zone ends, $\mathrm{Z}$ (Fig. 5e).

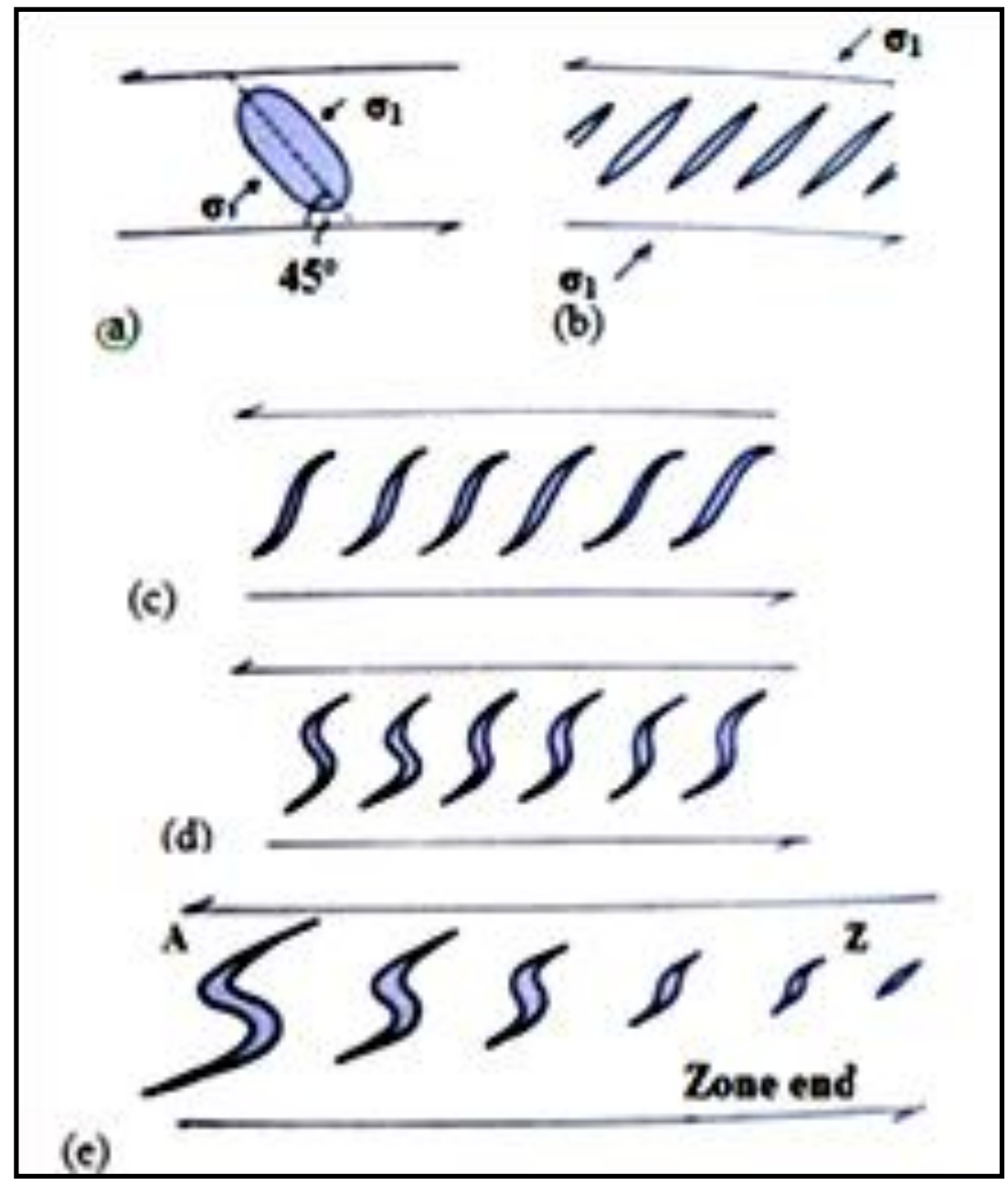

Fig. 5: (a.) The orientation of the maximum principle compressive stress with respect to a shear zone and the strain ellipse associated with the first increment of shear deformation. The eccentricity of the ellipse is exaggerated for clarity. (b- e) The formation of en echelon tension gashes within a shear zone in response to this stress, after Price and Cosgrove (1990). 
Each quartz-filled vein is really an extension gash that has its long axis parallel to the direction of incremental shortening and that opens in the direction of elongation in the rock. These arrays can seldom give us complete information on the finite strain $(\gamma)$ state.

\section{MATERIALS AND METHODS}

The studies are based mainly on the early detailed field radioactive measurements and mineralogical studies (Waheeb and El Sundoly 2016) at G-V shear zone uranium occurrence. Field photographs were taken for the investigated area. Detailed structural and field studies for the shear zone was followed by the analysis of data by using Ramsay and Huber 1983 strain equation, Delvaux and Sperner 2003 win Tensor computer program and Graphical analysis method of lisle 2013 enabling better understand for the structural deformation by using sigmoidal tension gashes for this radioactive shear zone.

\section{RESULTS AND DISCUSSION}

\subsection{Shear Zones}

The shear zone with extension gashes, which was recorded at G-V occurrence (Fig. 6), indicated that this shear zone is a brittle shear zone (Ramsay1980). An equal area stereographic projection (Fig. 7) was plotted for this shear zone in association with its tension gashes to determine the three principle stress axes attitude using the computer program Win Tensor (Delvaux and Sperner 2003). The following are the attitude of the three stress axes:-

1 - The principle stress axis $\sigma_{1}$ is plunging $69^{\circ}$ on bearing $48^{\circ}$.

2 - The intermediate stress axis $\sigma_{2}$ is plunging $20^{\circ}$ on bearing $213^{\circ}$.

3 - The least stress axis $\sigma_{3}$ is plunging $5^{\circ}$ on bearing $305^{\circ}$.
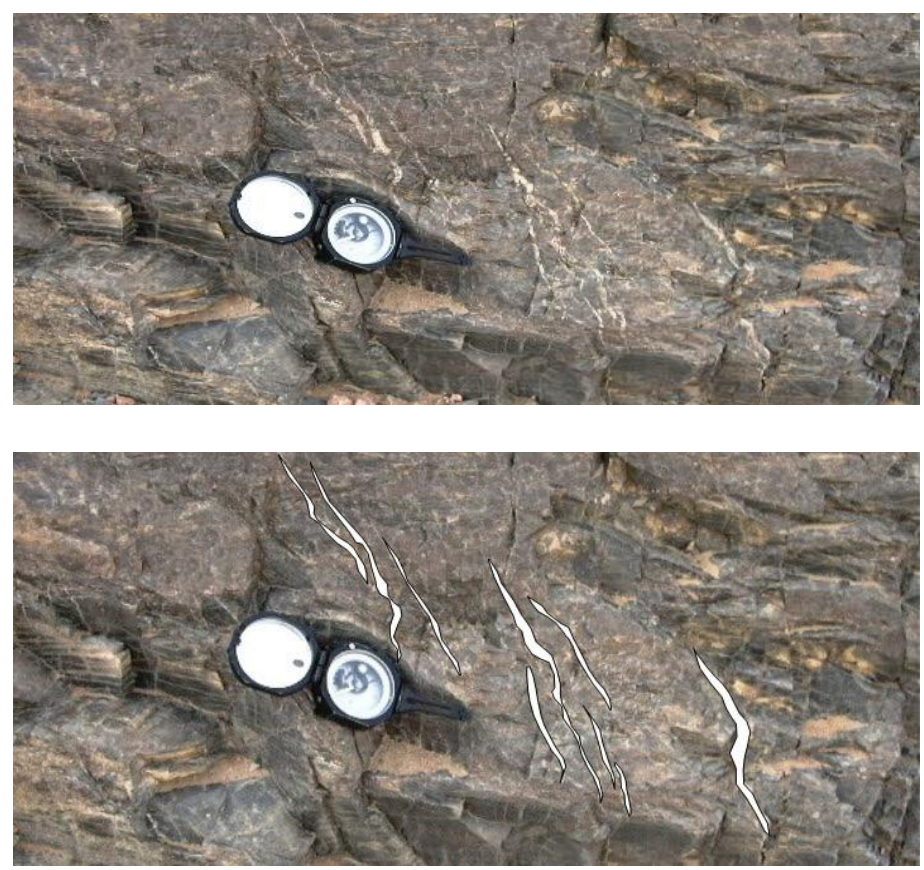

Fig 6: En echelon tension quartz gash array in the brittle shear zone of G-V occurrence, W. Belih area. 


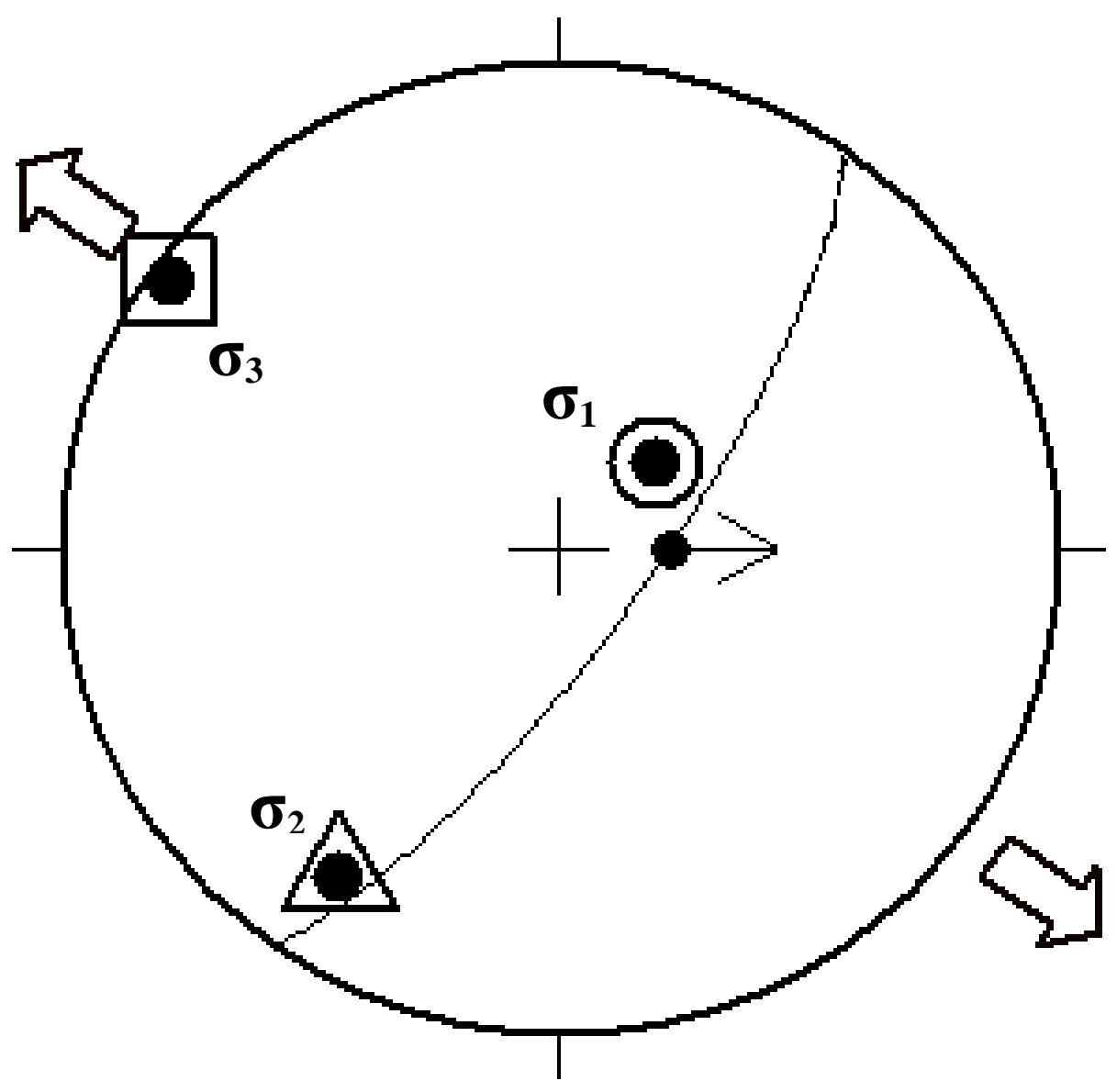

Fig. 7: Three principle stress axes for shear zone plane with tension gashes of G-V occurrence mineralized shear zone, $W$. Belih area.

It is clear from the result of the analysis that the extension force of NW-SE direction is the main extensional force that affected the G-V mineralized tensile shear zone; this result is the same as the structural analysis that indicated from fault slip data paleostress analysis (Waheeb and El Sundoly 2016). This extension force is responsible for the distribution and localization of secondary uranium minerals in the G-V shear zone.

\subsection{Estimated Strain for G-V Mineralized Shear Zone}

Sigmoidal tension gashes are mineral veins with a characteristic geometry. They occur in arrays in which the individual veins in cross-section are s-shaped and are thicker in their central parts and a taper in thickness towards their ends (figures 5 and 6). Within each array, adjacent veins exhibit an en echelon or overlapping arrangement. In many cases, it is clear from the associated deformation feature that the array of sigmoidal tension gashes occupies a shear zone.

Sigmoidal tension gashes have major implications for the analysis of shear zones. In particular, the calculation of the strain distribution across a particular shear zone using sigmoidal tension gashes as strain markers. This paper considers the issue of determining strain and its localization from the geometrical analysis of sigmoidal 
tension gashes in two-dimensional and take no account of deformation in the third dimension.

There are different types of gash arrays that are distinguished (Beach 1975) based on the orientation of the precursor fracture. In the case of the extensional fractures formed during true (isochoric) simple shear, the expected orientation is 45 with respect to the shear zone boundary but would be at a lower or higher angle when there is respectively a positive or negative volumetric strain component.

Tension gashes may develop by the dilation of pre-existing fractures (Ramsay 1967; Smith 1999). In the absence of information on the original fracture orientation $(\alpha)$. An estimate can be obtained from the orientation of the gash tip at the edge of the shear zone (Fig. 8). The final shape of the gash will depend on the type of deformation; whether or not volume changes have accompanied simple shear (Ramsay and Huber 1983 , p. 51), and on the relative timing of the simple shear and volumetric deformations. For the case of ideal simple shear, the shear strain at points within the shear zone can be calculated by rearranging the following equation (Ramsay and Huber 1983, p. 24).

$$
\gamma=\cot \alpha-\cot \alpha^{\prime}
$$

Where $\alpha$ and $\alpha^{\prime}$ are respectively the initial fracture orientation (i.e., gash tip) and the deformed vein orientation at points along the curved gash (figures 8 and 9A). The finite shear strain $(\gamma)$ within the G-V shear zone can be calculated as following:

$$
\begin{gathered}
\gamma=\cot \alpha-\cot \alpha^{\prime} \\
\gamma=\cot 45^{\circ}-\cot 54^{\circ} \\
\gamma=1-0.73=0.27
\end{gathered}
$$

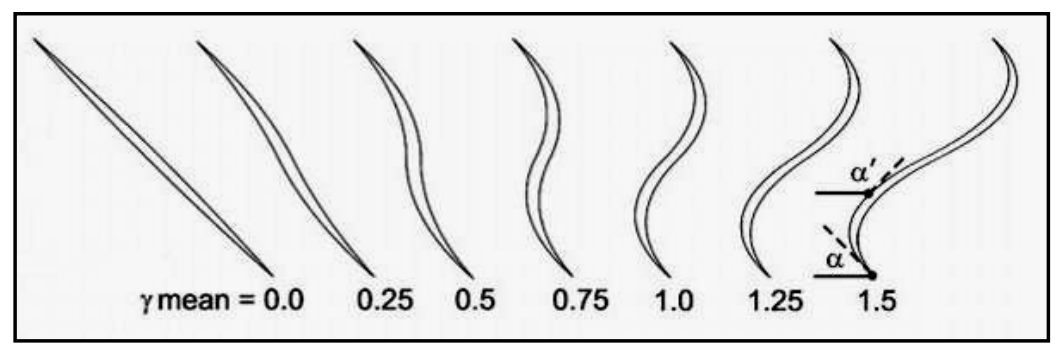

Fig 8: Progressive evolution of gash shape with an increase in the average shear strain across the shear zone.

\subsection{Graphical Method of Analysis (Lisle Method)}

Strain analysis from a given tension gashes array is done for the most important zones responsible for the localization and distribution of uranium minerals in (G-V uranium occurrence) by using the lisle method (lisle 2013). This method is a simple graphical technique that estimates the simple shear strain Dx and a volume strain component Dy. $(\mathrm{dx})$ is the component parallel to the shear boundary and produces a simple shear, whilst (dy) is the boundary-normal component and expresses a bulk volume change of the 
shear zone. Dx and Dy are $\mathrm{dx}$ and dy respectively, normalized by dividing by the original zone width (w) of the shear zone (Fig. 9).

Estimates of shear zone simple shear strain $D x$ and a volume strain component $D y$ from sigmoidal tension gashes can be obtained using the following procedure:

1) Data consisting of the angles $\alpha$ and $\alpha^{\prime}$ are measured (Fig. 9A).

2) A circle of arbitrary radius and center ( $p$ ) is drawn (Fig. 9B).

3) A line is drawn through point $p$ with a direction perpendicular to the initial gash orientation. This line cuts the circle's circumference at ( $q$ ) (Fig. 8B).

4) A line through $(q)$ is drawn in the direction of the line that joins the two tips of the tension gash. This meets the circle at $(r)$. The arc $(q r)$ characterizes the shape of the idealized constant curvature folds of the gash and its arc-length is the original length of the gash $(L)$.

5) The stretch, $S$, of the line ( $q r)$ is found by using the equation:

$$
S=\sin \left(\alpha^{\prime}-\alpha\right) /\left(\alpha^{\prime}-\alpha\right)
$$

where angles are in radians

$$
S=\sin 9^{\circ} / 9^{\circ}=0.0174
$$

6) The original precursor fracture can now be constructed as the line through $(r)$ that makes angle $\alpha$ with the shear zone boundary.

7) Along the line drawn in (6), point $(s)$ is located such that:

$$
\text { Length } s r=S \times \text { length }(q r)
$$

Line $(s r)$ represents the original fracture.

8) Points $(s)$ and $(q)$ are the tips of the fracture in the original and deformed states respectively, and therefore provide reference points for the measurement of displacement components, $(d x=1.2)$ and $(d y=4)$. Since the latter are of undefined scale, they can best be expressed as proportions of the shear zone's original width, $w=14.3$ (Fig. 8 b) to give $D x$ and $D y$ respectively.

The simple graphical method yields a shear strain $(d x / w=D x)$ of 0.084 and a volume increase $(d y / w=D y)$ of $28 \%$. 


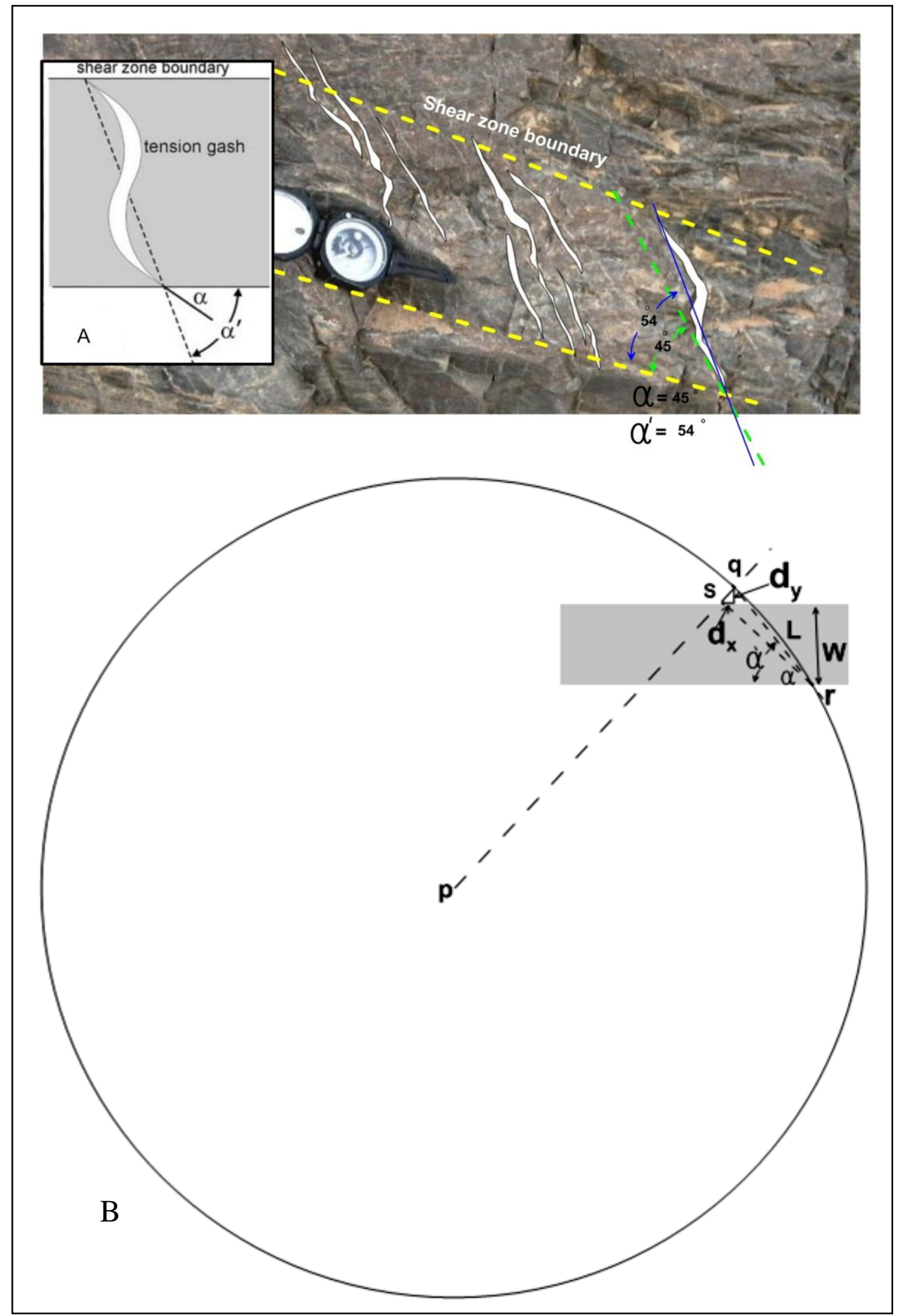

Fig 9: A graphical method for estimating shear strain from sigmoidal gashes of the brittle shear zone of $G-V$ uranium occurrence, W. Belih area. 
The analysis indicates that $D x$ is a small value $(D x=0.084)$.so that, the progressive opening of the tension gashes implies an increase in volume which must result in a widening of the shear zone since the gashes themselves undergo deformation at constant volume. Hence at this stage, an increase in zone-parallel displacement $D x$ is associated with an increase in dilatation $D y$. The rate of dilatation relative to boundary-parallel shear $D x$ is greatest as the finite strain is low $(\gamma=0.27)$, so that space is created rapidly for the precipitation of minerals. This result coincides with (lisle 2013) analysis and results.

\section{Conclusion}

Sigmoidal tension gashes are mineralized veins with a characteristic geometry. They are useful markers for the determination of structural deformation, which affected the mineralized G-V shear zone along W. Belih area. They indicate that this shear zone is a brittle shear zone, as well as the shear zone in association with its tension gashes, give an extension regime from the NW-SE direction. The extension force of the NW-SE direction is the main extensional force affecting the G-V mineralized shear zone and is responsible for the distribution and localization of secondary uranium minerals.

The strain analysis for the sigmoidal tension gashes indicates that $D x$ is a small value $(\mathrm{Dx}=0.084)$. So that, the progressive opening of the tension gashes implies an increase in volume, which must result in a widening of the shear zone since the gashes themselves, undergo deformation at constant volume. Hence, at this stage, an increase in zone-parallel displacement $D x$ is associated with an increase in dilatation $D y$. The rate of dilatation relative to boundary-parallel shear $D x$ is greatest as the finite strain is low $(\gamma=0.27)$, so that space is created rapidly for the precipitation of minerals.

\section{REFERENCES}

[1] Abdel-Hamid, A. A.: "Geologic factors controlling the radon emanation associated with uranium mineralizations along Wadi Belieh, North Eastern Desert, Egypt". Unpublished M. Sc. Thesis, 189pp. Faculty of science, Benha Univ., Egypt, (2006).

[2] Amin, N. F.: "Surface and subsurface structural features controlling uranium mineralizations at granitic-hammamat contact, Wadi Belieh, Northern Eastern Desert, Egypt". Unpublished Ph. D. Thesis, 98pp. Faculty of Science, Ain Shams University, Egypt, (2010).

[3] Beach, A.: "The geometry of en-echelon vein arrays". Tectonophysics 28, pp. 245263, (1975).

[4] Dardir, A. A. and Abu Zeid, K. M.: "Geology of the basement rocks between lat. $27^{\circ}$ $00^{\circ}$ and $27^{\circ} 30^{\circ}$ N., Eastern Desert". Ann. Geol. Surv. Egypt, 11, pp. 129-159, (1972).

[5] Delvaux, D. and Sperner, B.: "New aspects of tectonic stress inversion with reference to the TENSOR program". Geological Society, London, Special Publications, 212, pp. 75-100, (2003).

[6] EL Gaby, S.: "Architecture of the Egyptian Basement Complex". International Basement Tectonics Assoc., 5, pp. 1-18, (1983).

[7] El Gaby, S.; List, F. K. and Tehrani, R.: "Geology, evolution and metallogenesis of the Pan-African belt in Egypt". In S. El Gaby and R .O. Grelling (eds). The PanAfrican belt in NE Africa and adjacent areas. Vieweg, Braunscheweig, pp. 17-68, (1988). 
[8] El-Kammar, A. M.; Salman, A. E.; Shalaby, M. H. and Mahdy, A. I.: "Geochemical and genetical constraints on rare metals mineralizations at the central Eastern Desert of Egypt". Chemical Journal 35, pp. 117-135, (2001).

[9] El Kazzaz, Y. A.: "Active faulting along Qena-Safaga road". $1^{\text {st }}$ Int. Conf. on the Geology of Africa, Assuit Univ., Egypt, 2, pp. 34-58, (1999).

[10] El Rakaiby, M. L. and Shalaby, M. H.: "Geology of Gabal Gattar batholith, Central Eastern Desert, Egypt". Int. J. Remote Sensing, 13, pp. 2337-2347, (1992).

[11] El Ramly, M. F.; Bundanov, V. I. and Hussein, A. A.: "The alkaline rocks of south Eastern Desert". Geol. Surv. Egypt, 53, 111p, (1971).

[12] El Shazly, E. M.: "Evolution of granitic rocks in relation to major tectonic". West Commemoration. Sagar Univ., India, 11, pp. 569-581, (1970).

[13] El Sirafy, A. M. and Rabie, S. I.: "Contribution of aeromagnetic to structural mapping of Gabal Gattar area, North Eastern Desert, Egypt". J. African Earth Sci., 10, No. 3, (1989).

[14] Hamimi, Z.: "Kinematics of some major shear zones in the Eastern Desert of Egypt". Egyptian Journal of Geology, 43, pp. 53-71, (1999).

[15] Hashad, A. H.: "Present status of geochronological data on the Egyptian basement complex". Inst. App. Geol. (Jeddah), Bull. 4, pp. 31-46, (1980).

[16] Lisle, R. J.: "Shear zone deformation determined from sigmoidal tension gashes". J. Struc. Geol., 50, pp. 35-43, (2013).

[17] Mahdy, A. A.: "Petrological and geochemical studies on the younger granites and hammamat sediments at Gabal Gattar-5 uranium occurrence, wadi Balih, North Eastern Desert, Egypt". Unpublished Ph. D. Thesis, 198pp. Faculty of science, Ain shams Univ., Egypt, (1999).

[18] Mahdy, M. A.; Salman, A. B. and Mahmoud, A. H.: "Leaching studies on the uraniferous Hammamat sediments, Wadi Bali, Northern Estern Desert, Egypt". 14 Congress of Mining and Metallergy, Edinburgh Scotlafd, pp. 229-235, (1990).

[19] Mahdy, N. M.; Shalaby, M. H.; Helmy, H. M.; Osman, A. F.; El-Sawy, E. H. and Abu Zeid, E. K.: "Trace and REE element geochemistry of fluorite and its relation to uranium mineralizations, Gabal Gattar Area, Northern Eastern Desert, Egypt". Arab Journal of Geoscience: DOI 10.1007/s12517-013-0933-2, (2013).

[20] Price, N. J. and Cosgrove, J. W.: "Analysis of geological structures". Cambridge University, London: pp. 465-470, (1990).

[21] Ramsay, J. G.: "Folding and fracturing of rocks". McGraw-Hill, New York, (1967).

[22] Ramsay, J. G.: "Shear zone geometry, a review". J. Struc. Geol., 2, pp. 83-89, (1980).

[23] Ramsay, J. G. and Huber, M. L.: "The techniques of Modern Stru. Geol., Vol. I: Strain Analysis". Academic Press, London, (1983).

[24] Roz, M. E.: "Geology and uranium mineralizations of Gabal Gattar area, North Eastern Desert, Egypt". Unpublished Ph. D. Thesis, 175pp. Faculty of science, Al Azhar Univ., Egypt, (1994).

[25] Salman, A. B.; EL Aassy, I. E. and Shalaby, M. H.: "New occurrence of uranium mineralization in Gabal Gattar, North Eastern Desert, Egypt". Ann. Geol. Surv., 16, pp. 31-34, (1986).

[26] Schmidt, D. L.; Hadley, D. G. and Stoesser, D.: "Late proterozoic crustal history of the Arabian Shield". Inst. Applied Geol., Jeddah, Bull. 3, 2, pp. 41-58, (1979). 
[27] Shalaby, M. H.: "Uranium mineralizations in northern Gabal Qattar locality, northern Eastern Desert". $7^{\text {th }}$ Conf. Phanerozoic and Develop. Al Azhar Univ., Cairo, 3, 19p, (1990).

[28] Smith, J. V.: "Inter-array and intra-array kinematics of en echelon sigmoidal veins in cross-bedded sandstone, Merimbula, southeastern Australia". Journal of Structural Geology, 21, pp. 387-397, (1999).

[29] Waheeb, A. G. and El Sundoly, H. I.: "Structure roles for the localization of metasomatite uranium deposit type at Wadi Belih area, Northern Eastern Desert, Egypt". Egyptian Journal of Petroleum, 25, pp. 201-214, (2016).

[30] Willis, K. M.; Stern, R. J. and Clauer, N.: "Age and geochemistry of late Precambrian sediments of Hammamat series from the north of Eastern Desert of Egypt". Precamb. Res., 42, pp. 173-187, (1988). 